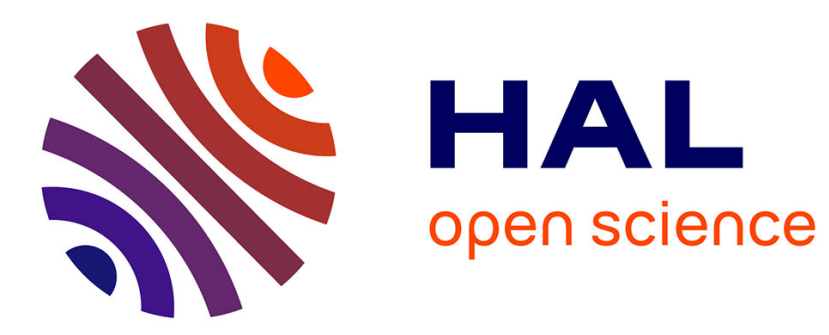

\title{
Passivation of intragrain defects by copper diffusion in p-type polycrystalline silicon
}

\author{
M. Zehaf, G. Mathian, C.M. Singal, S. Martinuzzi
}

\section{To cite this version:}

M. Zehaf, G. Mathian, C.M. Singal, S. Martinuzzi. Passivation of intragrain defects by copper diffusion in p-type polycrystalline silicon. Revue de Physique Appliquée, 1983, 18 (9), pp.557-560. 10.1051/rphysap:01983001809055700 . jpa-00245116

\section{HAL Id: jpa-00245116 https://hal.science/jpa-00245116}

Submitted on 1 Jan 1983

HAL is a multi-disciplinary open access archive for the deposit and dissemination of scientific research documents, whether they are published or not. The documents may come from teaching and research institutions in France or abroad, or from public or private research centers.
L'archive ouverte pluridisciplinaire HAL, est destinée au dépôt et à la diffusion de documents scientifiques de niveau recherche, publiés ou non, émanant des établissements d'enseignement et de recherche français ou étrangers, des laboratoires publics ou privés. 


\title{
Passivation of intragrain defects by copper diffusion in p-type polycrystalline silicon ${ }^{+}$
}

\author{
M. Zehaf, G. Mathian, C. M. Singal (*) and S. Martinuzzi \\ Laboratoire de Photoélectricité, Faculté des Sciences et Techniques de Marseille, \\ F 13397 Marseille Cedex 13, France
}

(Reçu le 28 mars 1983, révisé le 16 mai, accepté le 6 juin 1983)

\begin{abstract}
Résumé. - Pour passiver les défauts cristallographiques dans du silicium polycristallin Wacker de type $p$, du cuivre a été diffusé à basse température $\left(\leqslant 500^{\circ} \mathrm{C}\right)$. Les échantillons ayant subi la diffusion de cuivre présentent des longueurs de diffusion effectives des porteurs minoritaires homogènes et aussi élevées que dans les meilleures régions des échantillons non traités. Les balayages photoélectriques montrent que la réponse des grains est améliorée après la diffusion de cuivre, tandis que l'activité recombinante des joints de grains est accrue.
\end{abstract}

\begin{abstract}
In order to passivate structural defects which degrade electronic properties, copper was diffused in p-type Wacker polysilicon at low temperature $\left(\leqslant 500^{\circ} \mathrm{C}\right)$. Copper diffused samples exhibit homogeneous values of effective minority carrier diffusion lengths, which are practically as high as the higher values measured in the starting material. Light beam induced current scannings indicate that the grain responses are improved after copper diffusion while the grain boundary recombination activity is enhanced.
\end{abstract}

\section{Introduction.}

The potential economic advantages of the use of low cost polycristalline silicon for solar cells and (in the future) for electronic devices will be realized if the detrimental effect of grain boundaries and intragrain defects (subgrain boundaries, dislocations...) [1] could be reduced. These structural defects can be particularly active when they segregate impurity atoms and this will be certainly the case with polysilicon prepared by means of fast growth technics with solar grade starting silicon.

Consequently the study of the passivation of all these defects is essential.

Seager [2] has recently shown that annealings in atomic hydrogen can passivate grain boundaries, however this passivation needs long expositions to hydrogen plasma and the stability of the result is not established over a large period. The passivation by metallic impurities could produce stable cure of defects by means of fast and economical processes, and copper appears as a suitable impurity.

Indeed, copper concentrations up to $10^{15} \mathrm{~cm}^{-3}$ have no deleterious effect on $n-p$ junctions made with

$\left(^{+}\right)$This work was supported by CNRS-PIRSEM no 9530 .

(*) Present address : University of Roorkee, $D^{t}$ of Physics, Roorkee 247672, İndia. single crystals [3]. In structurally imperfect silicon, copper atoms migrate rapidly to the defect sites, and this decoration is a well established method to reveal lattice defects [4].

A first tentative was made by Daud and Koliwad [5] who have found that the presence of diffused copper improves the conversion efficiency of solar cells made with fine grained p-type silicon. For coarse grained silicon, the opposite effect was observed. With copper doped polycrystalline wafers the improvement occurs for fine and large grained materials. Daud and Koliwad explained their results on the basis of the segregation of copper to the grain boundaries, which reduces the minority carrier recombination. However this assumption is in disagreement with measurements reported by Kazmerski [6].

In this paper we present results obtained with low temperature copper diffused p-type Wacker polysilicon by means of diffusion lengths measurements and light beam induced current (L.B.I.C.) scannings. We can thus establish how a bulk property of polysilicon varies after diffusion of copper and we can localize the influence of this impurity.

\section{Experimental.}

Two p-type Wacker polysilicon wafers of $50 \times 50 \mathrm{~mm}$ in size, resistivity $\simeq 5 \Omega . \mathrm{cm}$, presenting practically the same mean grain size $(\simeq 0,4 \mathrm{~mm})$ and dislocation 


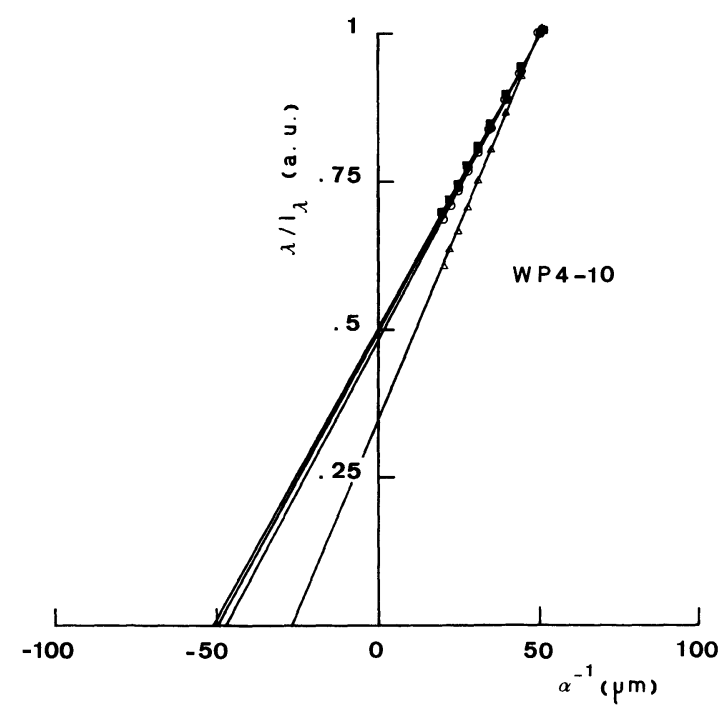

a)

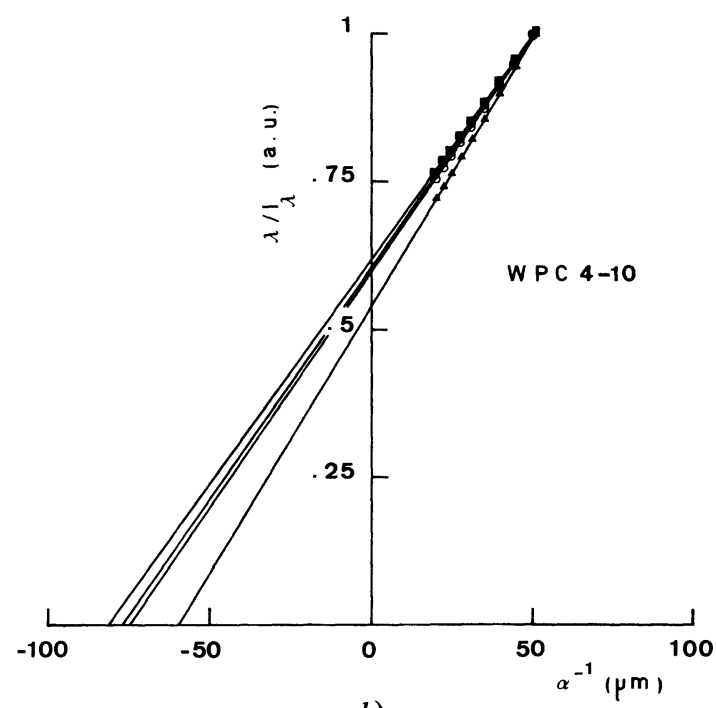

b)

Fig. 1. - Typical determinations of effective diffusion lengths in annealed (WP4) and copper diffused (WPC4) samples (temperature $400{ }^{\circ} \mathrm{C}$ ). (The ratio of wavelength $\lambda$ by photocurrent $I_{\lambda}$ is plotted versus the reverse absorption coefficient $\alpha_{\lambda}$ for different wavelengths $\lambda$.)

density $\left(\simeq 10^{4} \mathrm{~cm}^{-2}\right)$ were chemically etched and polished. On the two faces of one wafer, copper was deposited by electron gun evaporation. The two wafers were then annealed at $400{ }^{\circ} \mathrm{C}$ during one hour in vacuum, they were cut in twelve $25 \times 8 \mathrm{~mm}^{2}$ samples and chemically etched to remove the excess copper and the eventually contaminated surface. On each sample four semi transparent Schottky diodes $\left(3 \times 3 \mathrm{~mm}^{2}\right)$ were realized by evaporation of $200 \AA$ of chromium. The back ohmic contact was made by R.F. sputtering of titanium. The same sequence of operations was repeated for diffusion at $500^{\circ} \mathrm{C}$.

In these conditions of diffusion, the concentration of copper remains always less than $10^{15} \mathrm{~cm}^{-3}$.

Effective minority carrier diffusion lengths were measured by a variant of the surface photovoltage method (S.P.V.) and L.B.I.C. scannings were performed with an infrared light spot $(\lambda \geqslant 0.9 \mu \mathrm{m})$ of $10 \mu \mathrm{m}$ in size. Experimental details have been given in a previous publication [7].

\section{Results.}

The diffusion of copper at $400^{\circ} \mathrm{C}$ slightly increases the mean resistivity $\bar{\rho}$ which varies from $5.3 \Omega$.cm to $5.7 \Omega . \mathrm{cm}$ while at $500{ }^{\circ} \mathrm{C} \bar{\rho}$ reaches $7.2 \Omega . \mathrm{cm}$.

Figures $1 a$ and $1 b$ show respectively the typical determination of diffusion lengths $\left(L_{\mathbf{n}}\right)$ in the diodes of an annealed sample (WP4) and of a copper diffused sample (WPC-4) at $400^{\circ} \mathrm{C}$. (The undiffused samples present a large variation of $L_{\mathrm{n}}$ values depending on the defects contained in the investigated diodes).

In the copper diffused samples, the initial low values of $L_{n}$ are considerably improved, while the higher values are only slightly reduced, which yields a fairly good homogeneity. This is illustrated in table I where the mean values of $L_{\mathrm{n}}$ are given for undiffused and copper diffused samples at $400{ }^{\circ} \mathrm{C}$ and $500{ }^{\circ} \mathrm{C}$. For the sample (WP4-7), the value of $\bar{L}_{\mathrm{n}}$ is initially high and is slightly increased by copper diffusion while for the other samples, $\bar{L}_{\mathrm{n}}$ is drastically enhanced.

Figure 2 shows a typical L.B.I.C. scanning of an undiffused diode. The scanning is confused, the detrimental effect of intragrain defects is certainly predominant and the grain boundary recombination

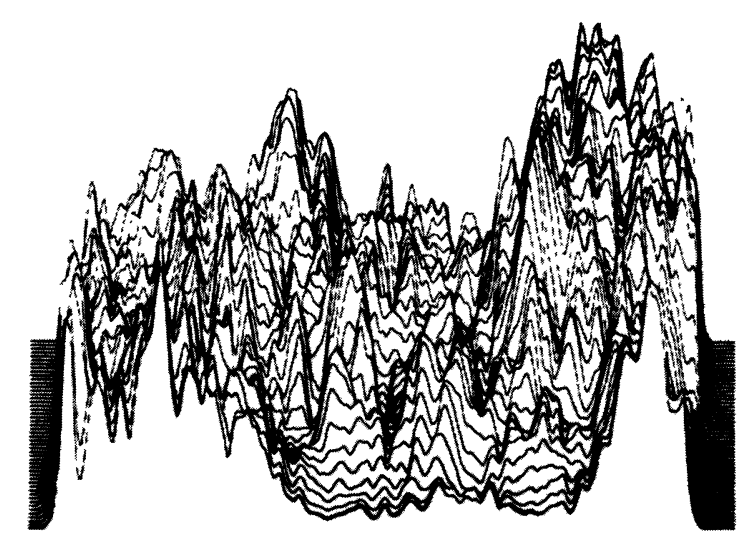

Fig. 2. - Light beam induced current scanning of a part of an annealed diode $\left(400^{\circ} \mathrm{C}\right)$.

activity is low or screened. As shown by the scanning of figure 3, after copper diffusion the responses of the grains are improved and smooth, the grain boundaries are clearly revealed by the photocurrent attenuations. The scanning is in agreement with the optical microphotography of figure 4 .

Similar results have been obtained for copper diffused samples, at $500^{\circ} \mathrm{C}$, except that the attenuations of photocurrent at grain boundaries are more severe. 


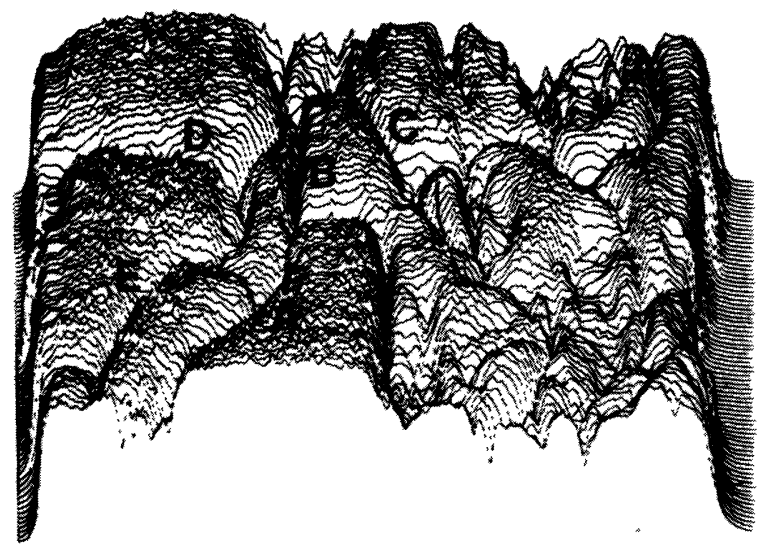

Fig. 3. - Light beam induced current scanning of a part of copper diffused diode $\left(400^{\circ} \mathrm{C}\right)$. The responses of the grains are improved and the grain boundaries are revealed by current attenuations (length of the diode : $3 \mathrm{~mm}$ ).

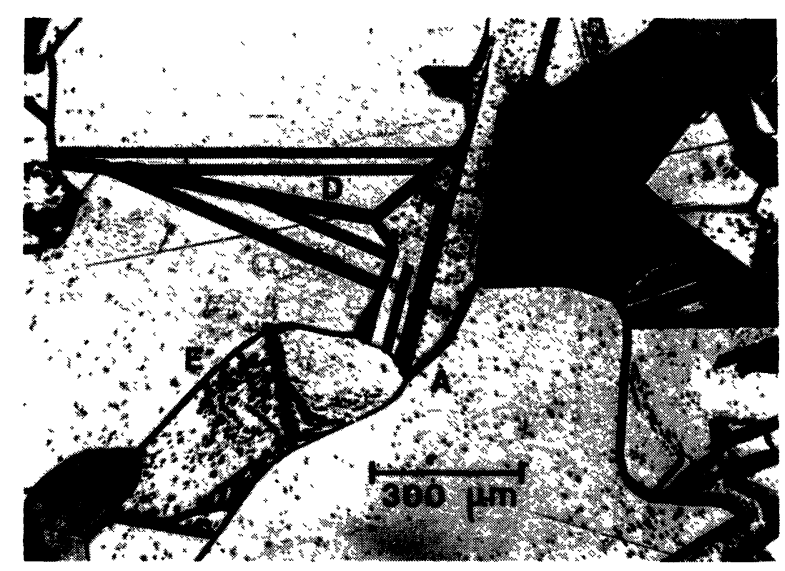

Fig. 4. - Microphotograph of a part of the copper diffused diode scanned in figure 3 . The correspondance with figure 3 is illustrated by the same letters along the same grain boundaries.

\section{Discussion.}

We have previously shown that effective diffusion lengths in polysilicon are dependent on grain boundary and dislocation densities [8], and also that in large grained materials the influence of intragrain defects becomes predominant, when their density is sufficiently large. Dislocations and grain boundaries can act as efficient recombination sites and it is believed that the structure of high angle grain boundaries may be described in terms of a dense array of lattice dislocations [9]. Thus the electrical properties of grain boundaries are similar to those of dislocations, and the copper diffusion must produce the effect of passivation or enhancement of the recombination velocity.

-The present results indicate that grain boundaries become more active while intragrain defects are passivated after copper diffusion.

The reasons of this different behaviour may be explained as follows. Diffusion of copper in polysilicon at low temperature $\left(<500{ }^{\circ} \mathrm{C}\right)$ may be accepted to occur by a two step process : first migration along grain boundaries, then diffusion from grain boundaries into the grains. Due to the very high diffusivity of copper in silicon and to its marked change in solubility with temperature [4], copper atoms are easily precipitated at the lattice defects as interstitials.

It is also established that copper exists in silicon in the form of four independent species [10] : interstitial and substitutional species, and also two copper associated species. The three later species produce acceptor and donor deep levels, while interstitial species behaves as a shallow donor and is predominant in samples diffused at temperature below $900^{\circ} \mathrm{C}$ because of the precipitation of its species in the grains.

It may be that copper atoms segregated at the grain boundaries produce deep impurity levels which increase the barrier height of the grain and consequently the effective interfacial recombination velocity, while copper atoms precipitated in the grains, near dislocations, act as shallow donors, which can saturated the recombining and trapping deep levels associated to these defects.

Thus the amphoteric behaviour of copper in silicon may explain the opposite effects observed on grain boundaries and on intragrain defects.

\section{Conclusions.}

The present results suggest that the diffusion of copper at low temperature $\left(\leqslant 500^{\circ} \mathrm{C}\right)$ in polysilicon is essentially a migration via structural defects which increases the recombination activity of grain boun-

Table I. - Mean values of effective minoritif carrier diffusion lengths for undiffused and copper diffused samples at $400{ }^{\circ} \mathrm{C}$ and $500{ }^{\circ} \mathrm{C}$.

\begin{tabular}{|c|c|c|c|c|c|c|c|}
\hline $\begin{array}{c}\text { Annealing } \\
\text { at } \\
400^{\circ} \mathrm{C}-1 \mathrm{~h}\end{array}$ & Sample & WP4-7 & WPC4-7 & WP4-9 & WPC4-9 & WP4-10 & WPC4-10 \\
\cline { 2 - 7 } & $\overline{L_{\mathrm{n}}}(\mu \mathrm{m})$ & 73 & 86 & 57 & 72 & 43 & 73 \\
\hline $\begin{array}{c}\text { Annealing } \\
\text { at } \\
500^{\circ} \mathrm{C}-1 \mathrm{~h}\end{array}$ & Sample & WP5-3 & WPC5-3 & WP5-4 & WPC5-4 & WP5-9 & WPC5-9 \\
\cline { 2 - 7 } & $\overline{L_{\mathrm{n}}}(\mu \mathrm{m})$ & 59 & 81 & 61 & 82 & 50 & 72 \\
\hline
\end{tabular}


daries as reported by Kazmerski [6]. However this migration drastically passivates the intragrain defects, which yields a large improvement of effective minority carrier diffusion lengths, when these lengths are small, because a large density of intragrain defects is present in the investigated region.

This property of copper may be decisive for the future of large grained polysilicon applications.

\section{References}

[1] Mathian, G., Amzil, H., Zehaf, M., Crest, J. P., Psaila, E., Martinuzzi, S. and Oualid, J., Solid State Electron. 26 (1983) 131.

[2] Seager, C. H., Sharp, D. J., Panitz, J. K. G. and HANOKA, J. I., J. Physique Colloq. 43 (1982) C1-103.

[3] Rohatgi, A., Davis, J. R., Hopkins, R. H., RaIChoudhury, P., McMullin, P. G. and McCorMICK, J. R., Solid State Electron. 23 (1979) 415.

[4] Shimokawa, R., Solid State Electron. 26 (1983) 97.

[5] Daud, T. and Koliwad, K. M., Effect of copper impurity on polycristalline silicon solar cells. Conf. Record, 13th IEEE photovoltaic specialists conf. (1978) p. 503.
[6] Kazmerski, L. L. and Russel, P. E., J. Physique Colloq. 43 (1982) C1-171.

[7] Oualid, J., Bonfils, M., Crest, J. P., Mathian, G., Amzil, H., Dugas, J., Zehaf, M. and MartiNUZZI, S., Revue Phys. Appl. 17 (1982) 119.

[8] Amzil, H., Zehaf, M., Crest, J. P., Psaila, E., MarTinuzzi, S. and OuAlid, J., Solar Cells 8 (1983) 269.

[9] Read, W. T. and Schokley, W., Phys. Rev. 87 (1952) 835.

[10] Toyama, N., Solid State Electron. 26 (1983) 37. 